\title{
フェンタニル静脈内投与による術中・術後 疼痛管理の合併症・副作用とその予防対策
}

神立延久* 柴田康之* 廣川 満* 堀場 清* 小松 徹*

\begin{abstract}
[要旨] 術後鎮痛目的にフェンタニル持続静脈内投与した 457 症例でその有効性と 合併症・副作用について検討した。病棟帰室時意識清明, 帰室後傾眠傾向, 覚醒不良 であった症例はおのおの 299 例(65.4\%), 148 例(32.4\%), 10 例(2.2\%)で あった．また，不穏・せん妄を 3 例 $(0.7 \%)$ に認めた. 舌根沈下を生じた症例が 17 例 (3.7\%) あった．短時間の無呼吸を 2 例 (0.4\%)で認めた．術後 $\mathrm{SpO}_{2}<90 \%$ 呈した症例は 20 例 (4.4\%)であった．徐脈（心拍数 $<50 \mathrm{bpm}$ )，低血圧(収縮期血 圧＜90mmHg) を呈した症例はおのおの 10 例(2.2\%), 43 例(9.4\%)であった. 術後嘔気を生じた症例は 97 例(21.2\%)で，そのうち 55 例 (12.0\%)に嘔吐を認 めた. 約半数の症例は術後鎮痛が十分得られた. フェンタニル持続投与による術後鎮 痛法は重篤な合併症がみられず, 術後痛対策の一法として有効であると考えられる. キーワード : フェンタニル, 持続静脈投与, 術後鎮痛
\end{abstract}

(日臨麻会誌 Vol.24 No.10, 655 664, 2004)

\section{はじめに}

術後患者の quality of lifeの向上や，ハイリスク患 者における術後の予後改善等を目的として現在, 術 後鎮痛が行われているが, 本邦においてはその主体 は硬膜外鎮痛法である ${ }^{1)}$. しかし頭頸部手術や脊椎 手術，また出血傾向のある症例や非協力的な患者に 対しては硬膜外鎮痛法を施行することはできない. 当院では, おもにこのような硬膜外鎮痛法が適応と ならない症例に対し，フェンタニル持続静脈内投与 による術中・術後疼痛管理を行い良好な成果をあげ
ている．本稿では，当院でのフェンタニル持続静脈 内投与による術中・術後疼痛管理方法について紹介 し, 術後合併症・副作用の現状とその予防対策につ いて述べる.

I 当院におけるフェンタニル持続静脈内投与に よる術中・術後鎮痛方法について

1. 術中のフェンタニル投与法の概要

患者の年齢，体重，術前の全身状態等に応じ，麻 酔導入時と手術開始時におのおのフェンタニル50〜 $200 \mu \mathrm{g}$ を静脈内ボーラス投与する。術中は，さらに 
手術侵襲を考慮に入れ, 薬物動態シミュレーション によりフェンタニルの推定効果器濃度を $1 \sim 3 \mathrm{ng}$ ・ $\mathrm{m} l^{-1}$ に維持するようにフェンタニルを静脈内ボーラ 又投与あるいは持続投与する。手術終了時のフェン タニルの推定効果器濃度が 1 〜 $\mathrm{ng} \cdot \mathrm{m} l^{-1}$ となるよう に投与量を調節する。

\section{2. 術後のフェンタニル投与法の概要}

手術終了時, 場合によっては, 術中から薬液の充 填された携帯型ディスポーザブル注入器を用いてフェ ンタニルの持続静脈内投与を開始, 術後も継続する. フェンタニルの投与については, 各麻酔担当医が患 者の全身状態や手術侵襲を考慮し, 臨床的に判断し て投与量と投与時間を決定している。フェンタニル 投与量に関しては, $0.5 \mu \mathrm{g} \cdot \mathrm{kg}^{-1} \cdot \mathrm{h}^{-1}$ を基準とし，お よそ $0.3 \sim 0.7 \mu \mathrm{g} \cdot \mathrm{kg}^{-1} \cdot \mathrm{h}^{-1}$ の範囲で適宜増減して薬 液を調製，持続投与している.

\section{II 術後合併症・副作用の現状}

フェンタニル持続静脈内投与による術後鎮痛法 は，適切な薬液の調製と投与量・投与速度の設定を 行えば，静脈ルートに接続するだけで容易に施行可 能であり困難な手技を必要としない。そのため, 本
法における術後トラブルはフェンタニルによる副作 用が主体である。今回はその発生頻度を調査した。

$<$ 対象と方法 $>$

当院麻酔科にて，2002 年 1 月より 12 月までの 1 年 間に術後フェンタニル持続静脈内投与を施行された 505 症例のうち, 調査可能であった 457 症例を対象 とした。診療録と術後回診記録を基にした後ろ向き 研究により術後の意識レベル, 呼吸器系合併症・副 作用, 循環器系合併症 - 副作用, 嘔気 - 嘔吐, 術後 鎮痛効果について検討した。

$<$ 結果 $>$

今回，対象となった 457 症例の内訳は，男性 223 例，女性 234 例であった。年齢は 5 歳から 90 歳にわ たり，41〜 60歳が 156例，61〜80歳が177例と 41〜 80 歳で $72.9 \%$ を占めていた(表1).

表 1 年齢 - 性別症例数

\begin{tabular}{c|cc|c}
\hline 年齢(歳) & 男性 (人) & 女性(人) & 計(人) \\
\hline$\sim 20$ & 13 & 16 & 29 \\
$21 \sim 40$ & 36 & 45 & 81 \\
$41 \sim 60$ & 72 & 84 & 156 \\
$61 \sim 80$ & 95 & 82 & 177 \\
$81 \sim$ & 7 & 7 & 14 \\
\hline 計(人) & 223 & 234 & 457 \\
\hline
\end{tabular}

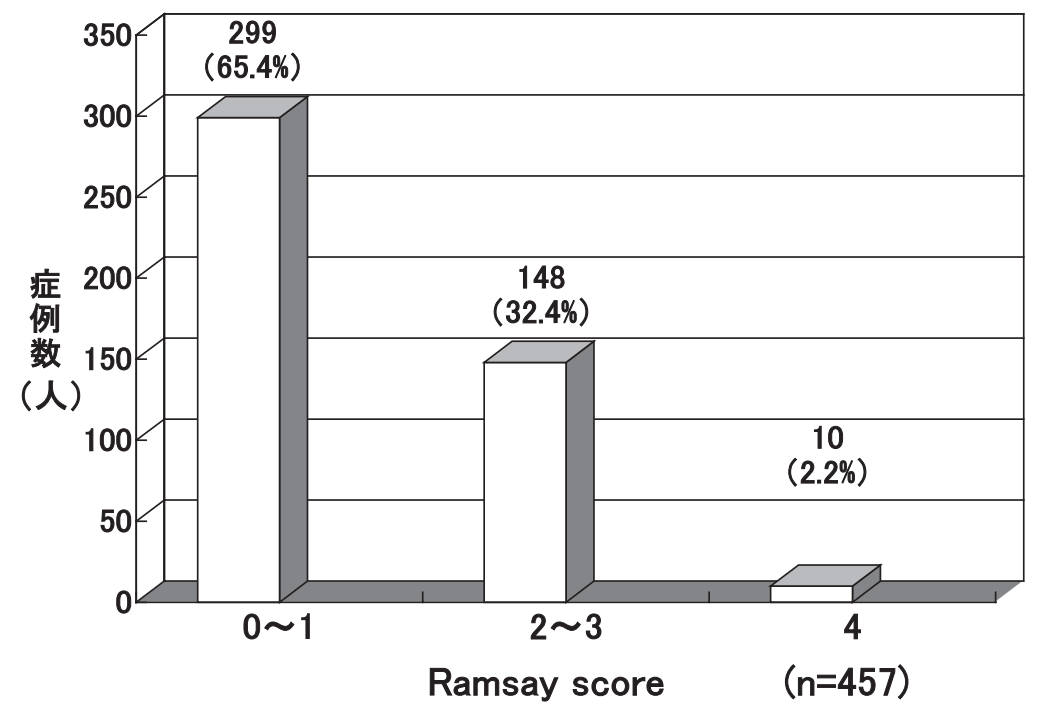

図1 意識レベル 病棟帰室後の意識状態 


\section{1. 意識レベル}

病棟帰室後の意識状態を Ramsay score を用いて 評価した. Ramsay score $0 \sim 1,2 \sim 3,4$ の症例は, おのおの，299例 (65.4\%)，148例 (32.4\%)，10例 (2.2\%)であった(図1)。術後不穏・せん妄状態を呈 した症例が 3 例みられた。 Ramsay score 4 の状態な らびに術後せん妄状態を呈した計 13 例の各年齢群に おける割合は，81歳以上の症例で $14.3 \%$ とほかの年 齢群に比べて高值であった(図2).

\section{2. 呼吸器系合併症・副作用}

術後呼吸器系合併症・副作用を生じた症例は, 457 症例中 40 例 $(8.8 \%)$ であった。17例 (3.7\%) に舌 根沈下を認め，このうち5例(1.1\%)で経鼻エアウエ イを必要とした。マスクによる酸素投与の有無にか
かわらず， $\mathrm{SpO}_{2}$ が $90 \%$ 以下を示した症例は 20 例 (4.4\%)であった。1 分間の呼吸数が 6 回以下の明ら かな呼吸抑制を呈した症例は 2 例 $(0.4 \%)$ であり，こ れらの症例はいずれも $\mathrm{SpO}_{2}$ が 90 \%以下を示してい た。また，術後無気肺，肺塞栓，術前よりの疾患に よる上気道閉塞症例をおのおの 1 例ずつ認めた（図 3). 舌根沈下, $\mathrm{SpO}_{2} 90 \%$ 以下の低酸素症(呼吸数 6 回・ $\min ^{-1}$ の呼吸抑制を含む)，術後無気肺などの術 後呼吸器系合併症・副作用を呈した 40 症例の各年齢 群における割合は，0〜 20 歳が $0 \% ， 21 〜 40$ 歳が $4.9 \%, 41 \sim 60$ 歳が $6.4 \% ， 61 \sim 80$ 歳が $13 \%$, 81 歳 以上が $21.4 \%$ と加齢に伴い増加した(図4).

\section{3. 循環器系合併症・副作用}

主として収縮期血圧と心拍数について検討した。

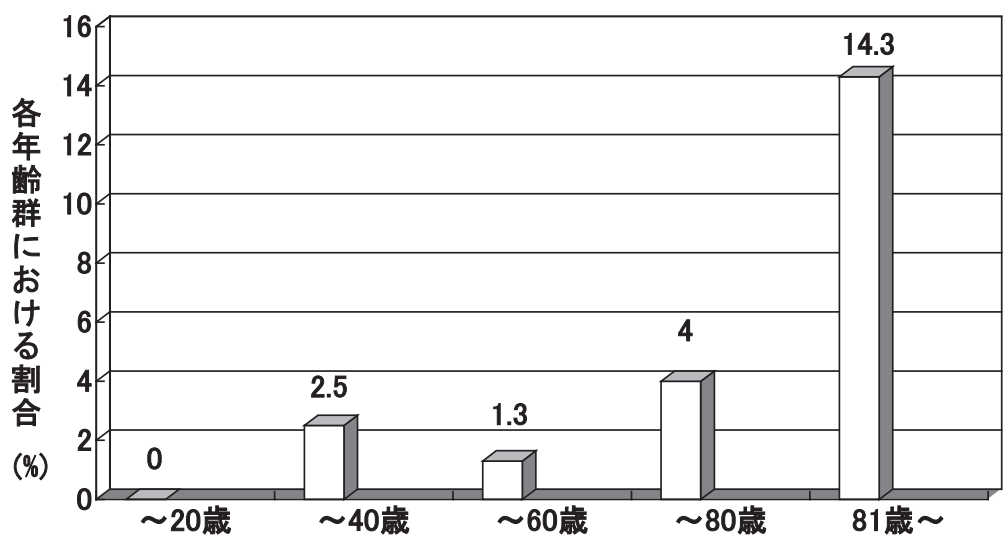

図2 意識レベル

Ramsay score 4 以上ならびにせん妄症例の各年齢群における割合

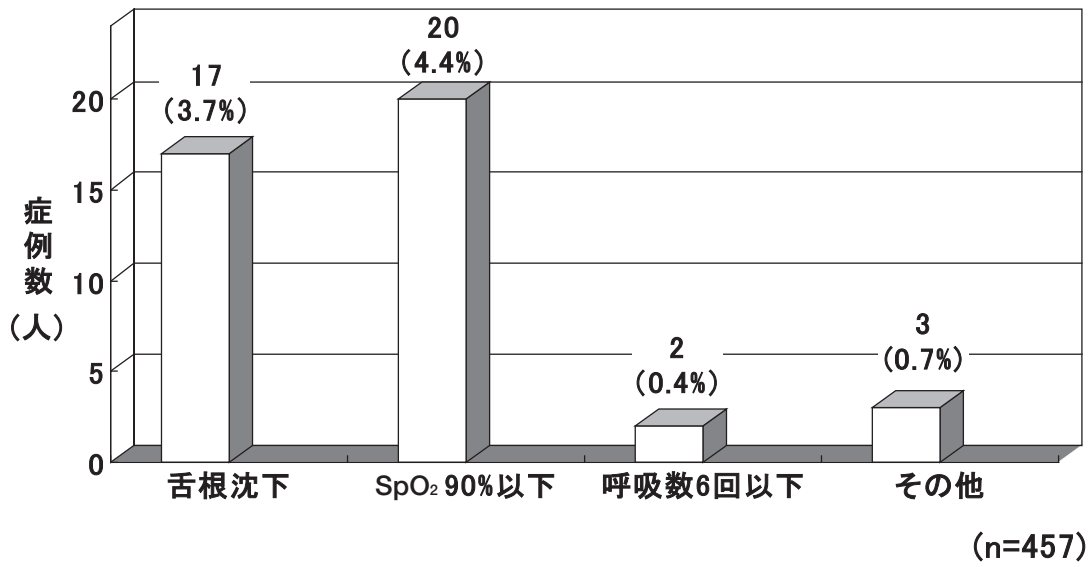

図3 呼吸器系合併症・副作用 


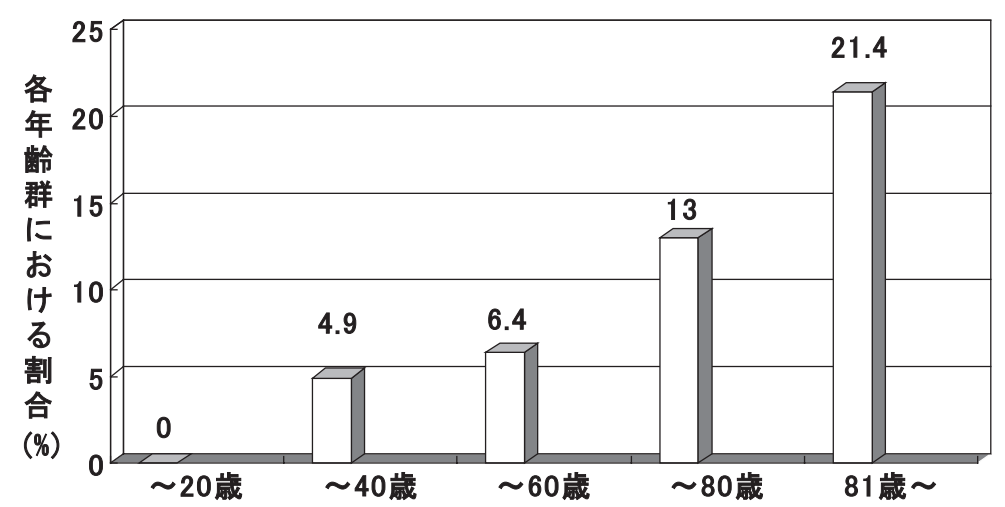

図4 呼吸器系合併症・副作用

各年齢群における割合

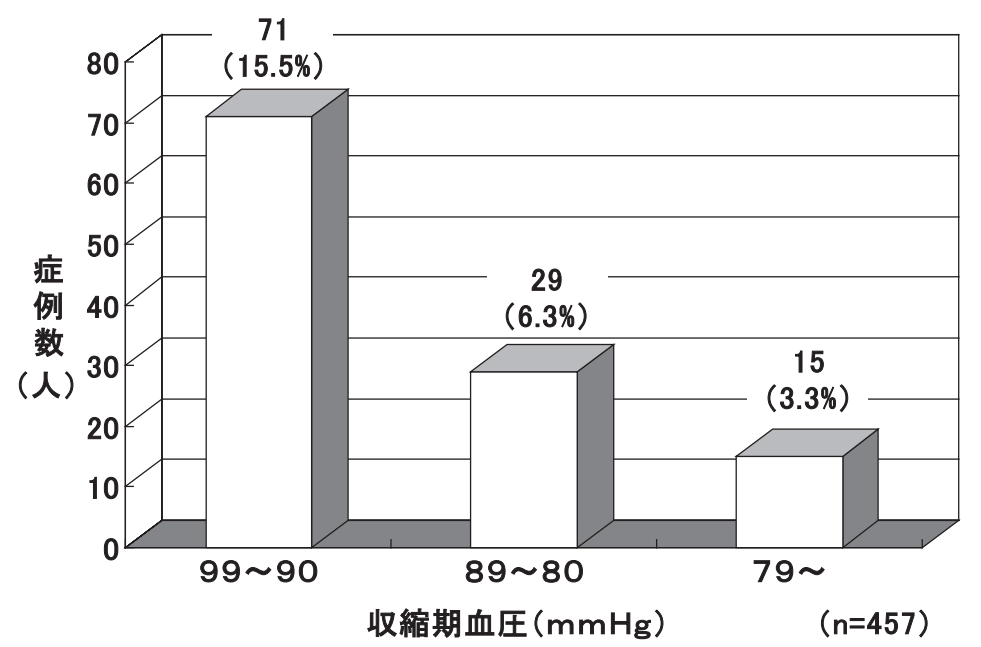

図5 循環器系合併症・副作用 1

収縮期血圧

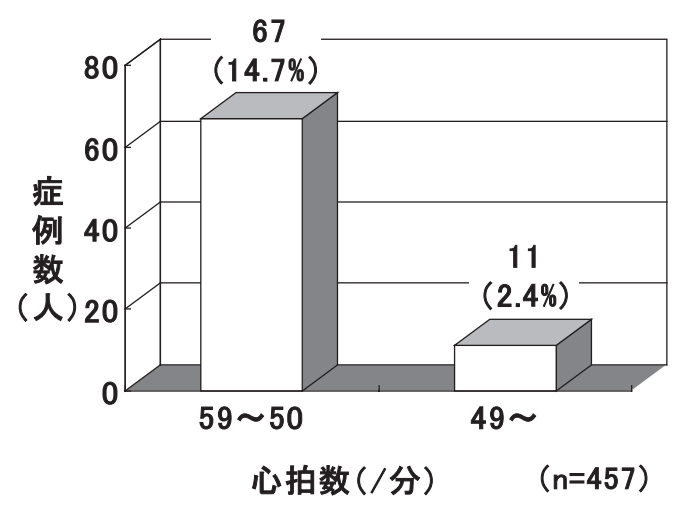

図6 循環器系合併症・副作用 2 心拍数

なんらかの術後循環器系合併症・副作用を生じた症 例は，457症例中 60 例 $(13.1 \%)$ であった。収縮期血
圧に関しては，当院における一般病棟管理では，収 縮期血圧が $90 \mathrm{mmHg}$ 未満で医師への連絡があるこ とが多いため, 今回の検討に際しては収縮期血圧 $90 \mathrm{mmHg}$ 未満を低血圧とした。 心拍数に関しては, 血圧が保たれていれば 50 〜 $60 \cdot \mathrm{min}^{-1}$ の心拍数は身 体に悪影響を及ぼさないと考え，今回の調査では $50 \cdot \mathrm{min}^{-1}$ 未満の症例を徐脈とした。 457 症例中, 収 縮期血圧 $80 \sim 89 \mathrm{mmHg}$ の症例が 29 例 (6.3\%), $80 \mathrm{mmHg}$ 未満の症例が 15 例 (3.3\%)であった(図5). 徐脈は 11 例 $(2.4 \%)$ に認められた (図6)。このうち の 1 症例は収縮期血圧が $80 \mathrm{mmHg}$ 未満であった。ま た，不整脈などの心電図異常を呈した症例は 6 例 (1.3\%) であった。術後循環器系合併症・副作用を 


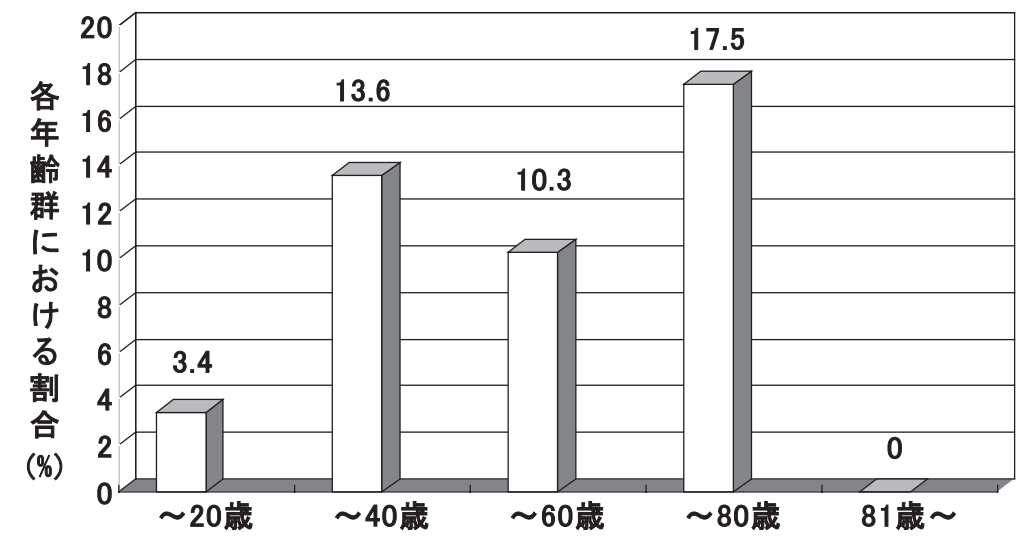

図 7 循環器系合併症・副作用

各年齢群における割合

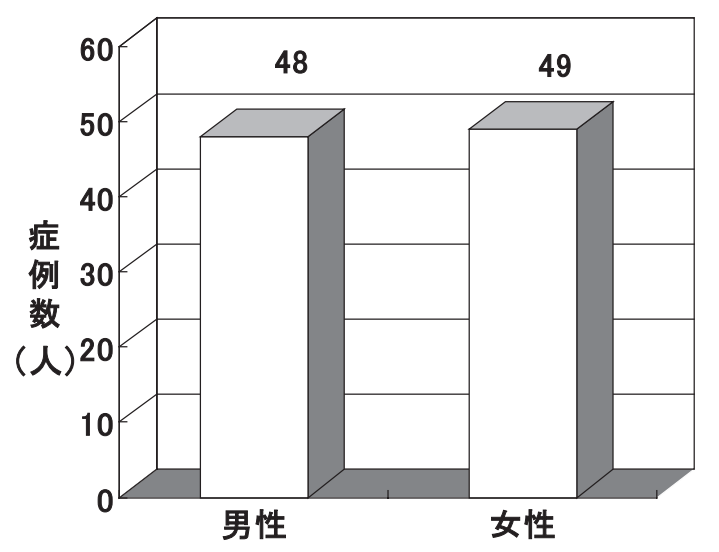

$(n=457)$

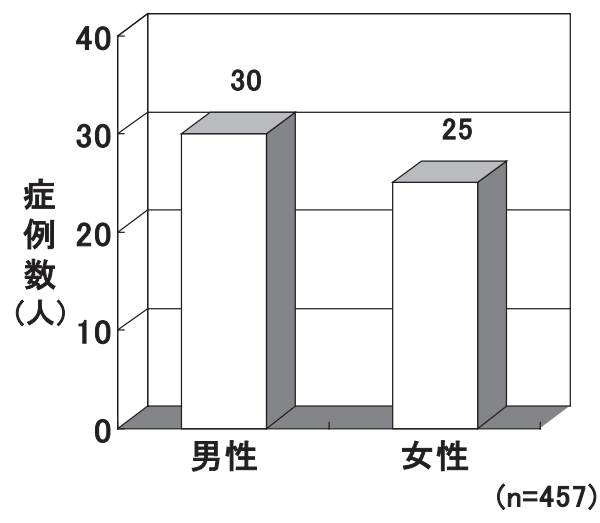

図9嘔吐

\section{図8 嘔気}

呈した 60 例の各年齢群における割合は，0～20 歳, $21 \sim 40$ 歳, $41 \sim 60$ 歳, $61 \sim 80$ 歳, 81 歳以上がそ れぞれ，3.4\%，13.6\%，10.3\%，17.5\%，0\%であっ た(図7)。

\section{4. 嘔気・嘔吐}

術後嘔気を生じた症例は, 457 症例中, 97 例 (21.2\%) であり，男性 48 例 (10.5\%)，女性 49 例 (10.7\%)であった(図 8)。嘔気を生じた 97 症例のう ち, 55例(全体の $12.0 \%$ )で嘔吐を認め，その内訳は， 男性 30 例 (6.6\%)，女性 25 例(5.5\%) であった（図9). 嘔気，嘔吐ともに有意な男女差は認められなかった。

\section{5. 術後鎮痛効果}

術後フェンタニル持続静脈内投与施行中に創部痛 を訴えた症例は 224 例 $(49.0 \%)$ であり，フェンタニ
ル持続静脈内投与以外の鎮痛薬を使用した症例は 220 例( $48.1 \%)$ であった.

術後 24 時間以内でのフェンタニル持続静脈内投 与以外の鎮痛薬使用回数の検討では，まったくほか の鎮痛薬を必要としなかった症例が 237 例 (51.9\%), 2 回未満が 153 例 (33.5\%)，2～ 3 回未満が 47 例 (10.3\%), 3 5 回未満が 18 例(3.9\%), 5 〜回未満, 7 回以上がともに 1 例 $(0.2 \%)$ であり, 2 回以上のフェ ンタニル以外の鎮痛薬を必要とした症例は，67例 (14.7\%)であった(図 10).

術後フェンタニル投与が中止されたのは 55 例で あり，中止理由としては，意識レベルの低下による 症例が 4 例 $(0.9 \%)$, 呼吸器系合併症・副作用による 症例が 9 例 $(2.0 \%)$, 循環器系合併症・副作用による 


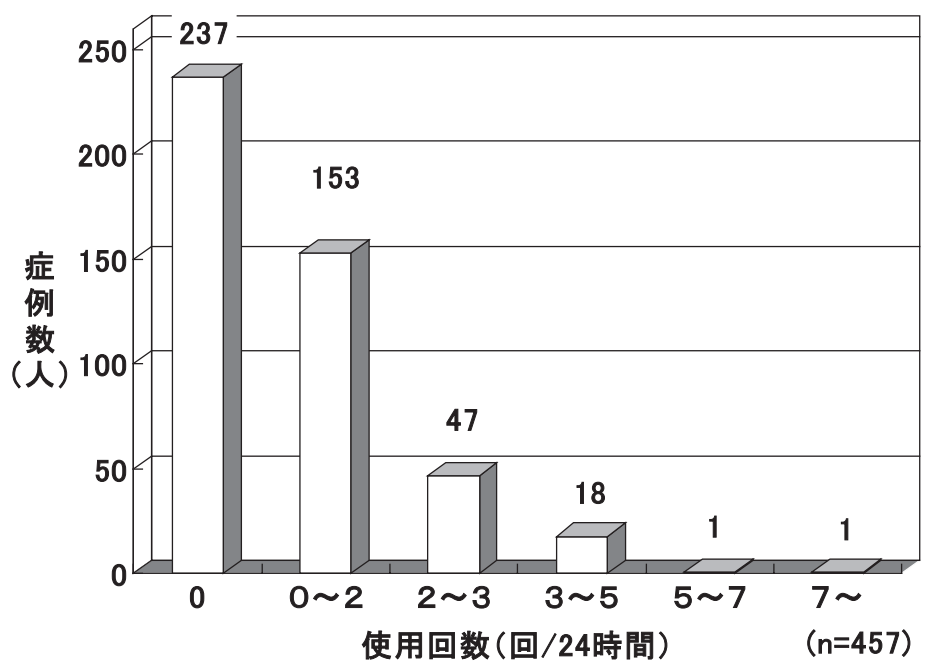

図 10 術後フェンタニル以外の鎮痛薬使用回数

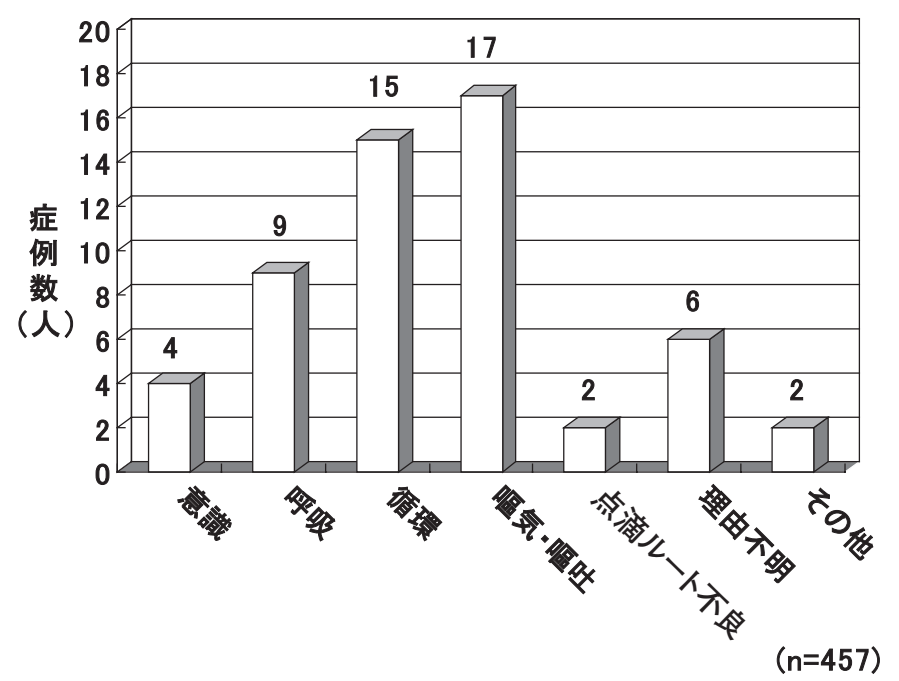

図11 術後フェンタニル投与中止理由

症例が 15 例 $(3.3 \%)$, 嘔気・嘔吐による症例が 17 例 $(3.7 \%)$, 点滴ルート不良による症例, そのほかが ともに 2 例 $(0.4 \%)$ ずつであった。また, 合併症・副 作用を認めないが，投与を中止された理由のはっき りしない症例が 6 例 $(1.3 \%)$ みられた(図11).

\section{III 術後合併症・副作用の対策}

\section{1. フェンタニル投与量の調整}

適切な鎮痛効果を得て, 合併症・副作用を最小限 にとどめるために最も重要な点がフェンタニル投与 量の調節である. 術後覚醒遅延や呼吸・循環抑制な
ぞのおもな要因であるフェンタニルの過剩投与を予 防することが重要である。フェンタニルに対する感 受性には個人差があるため, 完全には防止すること は困難であるが，当院では，PDA (Personal Digital Assistant) 装置を用いてフェンタニル効果器濃度を シミュレートして投与量を調節している.

\section{2. 術後酸素投与}

当院では全身麻酔施行症例に対し，術後数時間の マスクによる酸素投与を行っている。今回の調査で は，酸素投与中止後に $\mathrm{SpO}_{2}$ が低下する症例が多くみ られたため，低酸素症予防目的にフェンタニル持続 
静脈内投与中，あるいは手術翌日までは酸素投与を 継続するようにしている.

\section{3. 嘔気・嘔吐に対するドロペリドール投与}

術後嘔気・嘔吐の発生は生死にかかわるような重 篤な副作用ではないものの, 患者によっては術後痛 より苦痛となる。また嘔気・嘔吐に伴う体動により 術後創部痛が増強することがあり, 術後疼痛対策と してのオピオイド投与がその目的を達していないば かりか逆効果となってしまう。当院では, 嘔気・嘔 吐の予防として, 術中にドロペリドール0.625〜 $2.5 \mathrm{mg}$ を静注し, 術後は, ドロペリドールが 0.625 $2.5 \mathrm{mg} \cdot \mathrm{day}^{-1}$ で持続投与されるように調製されたフェ ンタニル・ドロペリドール混合液を充填した携帯型 ディスポーザブル注入器を用いてフェンタニルとと もにドロペリドールを投与している.フェンタニル はモルヒネに比べ副作用が少ないとされているが, オピオイドを使用している以上，この副作用を完全 に避けることは困難である。今後，ドロペリドール の適切な投与量のさらなる検討や, 作用機序の異な る制吐剂の使用, 手術開始前の神経ブロック併用や 術野での局所麻酔薬の使用による術後フェンタニル 投与量の減量等を考慮する必要がある.

\section{4. 術後患者の看視}

麻酔方法や術後鎮痛方法のいかんにかかわらず, 術後患者のバイタルサインのチェックは重篤な合併 症・副作用を予防するために重要である。しかし， 当院の現状は, 一般病棟帰室後は各科の主治医や病 棟看護師がおもにこれを行っている。麻酔科として は, マンパワーの問題もあり, 術後回診時のバイ夕 ルサインの確認程度という不十分な状態である。こ の問題点を改善するため, 現在, リカバリルームの 設置を進めている.リカバリルームの設置により少 数の人員で術後患者の看視が可能となり, バイタル サインの安定した状態で患者を病棟に帰室させるこ とができると考えている，また，各患者に対する鎮 痛薬の至適投与量を決定することが可能となり，よ り質の高い医療を患者に提供することができると期
待している.

\section{IV 考 察}

フェンタニル静脈内持続投与による術後鎮痛法 は，特殊な手技やトレーニングを必要とせず，薬液 の調製に注意すれば容易に施行することができる。 また，手術部位による制限を受けず，出血傾向のあ る患者に対しても用いることができるという利点も ある．現在，本邦における術後疼痛対策の主体は硬 膜外鎮痛法であり，当院でも硬膜外鎮痛を行ってい るが，上述のような硬膜外鎮痛法の適応とならない 症例や硬膜外カテーテル留置が困難な症例に対し て，フェンタニル静脈内持続投与による術後鎮痛を 積極的に施行している.

本法の問題点としては，硬膜外鎮痛法における硬 膜穿刺や硬膜外血腫形成のような手技に関連した合 併症はほとんどみられないことから，フェンタニル による副作用が主体となっている. 今回の術後副作 用の調査では，フェンタニルのおもな副作用である 意識レベルの低下，呼吸・循環抑制，嘔気・嘔吐に ついてその発生率を, 加えて鎮痛効果についても検 討した。

意識レベルについては, 全体の約 $1 / 3$ の症例で Ramsay score が 2 〜の適度な鎮静状態が得られ た. Ramsay score 4 の症例が 10 例 $(2.2 \%)$, 術後せ ん妄を生じた症例が 3 例みられ，81歳以上の患者群 における割合が $14.3 \%$ とほかの年齢群に比べ高值で あった。

呼吸器系合併症・副作用としては, 鎮静に伴う舌 根沈下 17 例 $(3.7 \%)$ と, 多くが酸素投与中止後に生 じた $\mathrm{SpO}_{2}$ の低下 $(90 \%$ 以下の症例は 20 例 ; $4.4 \%)$ が主体となった。呼吸器系合併症・副作用を呈した 40 例の各年齢群における割合は, 加齢に伴い増加す る傾向がみられた。

循環器系合併症・副作用としては，収縮期血圧 $90 \mathrm{mmHg}$ 未満の低血圧を 44 例 $(9.6 \%)$, 心拍数 50 ・ $\min ^{-1}$ 未満の徐脈を 11 例 $(2.4 \%)$ に認めた。また，術 
後新たに生じた不整脈などの心電図異常を 6 例認め た。これら 60 例における年齢別割合では明らかな傾 向はみられなかった。

今回の調査では, 術後の意識レベル低下や呼吸抑 制は, 術中に使用された吸入麻酔薬や静脈麻酔薬の 影響が残存していると考えられる帰室直後, あるい は術後病棟にてほかの鎮痛薬や鎮静薬が投与された ときに認められることが多かった。 とくに高齢者で は, フェンタニルに対する感受性がもともと高いた め ${ }^{1)}{ }^{2}$, ほかの鎮痛薬の併用によりフェンタニルの 効果が増強されると, 容易に意識レベルの低下や呼 吸抑制をきたすと思われ，高齢者におけるフェンタ ニル持続静脈内投与においては注意が必要である. 循環器系合併症・副作用について, 術後の血圧低下 は，高血圧の既往の有無を含めた術前の全身状態や 術中・術後出血など多くの要因に左右されるため, フェンタニルの副作用によるものと必ずしも判断で きない，そのため，フェンタニルの副作用としての 循環抑制を評価するには心拍数のみを用いるのが適 切であったと考えられる。

嘔気・嘔吐に関しては，嘔気が 97 例 $(21.2 \%)$ ，そ のうち，嘔吐を生じた症例が 55 例(12.0\%)であった。 その多くは術直後から術後数時間以内に発生した. 一般的には術後の嘔気, 嘔吐の訴えは女性の方が多 いとされているが今回の調査では嘔気, 嘔吐ともに 有意な男女差は認められなかった ${ }^{3)}$ 。その理由はあ らかじめ投与されているドロペリドールが関与して いる可能性がある。

術後鎮痛効果については, 約半数である 224 例 (49.0％) に疼痛の訴えを認め，そのほとんどの症例 (220例； 48.1\%) でフェンタニル以外の鎮痛薬を使 用している. しかし, 術後 24 時間以内に 2 回以上の

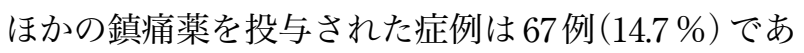
り, 術後痛の大半は体動時痛であったため, フェン タニル静脈内持続投与による術後鎮痛の効果として は満足できるものと考えている。疼痛の訴えは術後 早期のものが多く，この時期に NSAIDsなどのほか
の鎮痛薬を 1 回併用するのみで，それ以降疼痛の訴 えを認めなかった症例は本法が有効であったと判断 した. 術後のフェンタニル投与の中止理由としては, 嘔気・嘔吐が 17 例 $(3.7 \%)$ と最多であった。これは, 患者の直接的な訴えや他覚的に容易にわかる症状で あるため，また患者の苦痛が強いためと思われる. 理由の明白でない 6 例については，いずれも主治医 の指示でフェンタニルの投与を中止されていた。わ れわれは術後鎮痛を行うことにより早期離床が可能 になると考えているが，外科系の医師のなかにはフェ ンタニルの持続投与中は離床困難と思っている人が 多く，この術後フェンタニル投与に対する誤解によ り, 離床や術後リハビリを進める際にフェンタニル 投与が中止されてしまっているようである。また， いまだに本法施行中に麻薬拮抗性鎮痛薬を使用する 主治医もみられ ${ }^{4)}$ ，主治医や病棟スタッフの本法に 対する指導や理解が今後の問題としてあげられる.

今回の調査では検討していないが，オピオイドの 副作用として尿閉があげられる，当院では，全身麻 酔症例の大半が術後尿道カテーテル留置下に管理さ れているため，患者による尿閉の訴えはほとんどみ られない。一般的に術後尿道カテーテル留置に対す る患者の不快感等が問題となる場合がある。今回の 調査結果からは明言できないが，フェンタニル持続 静脈内投与は，尿道カテーテルや胃管チューブなど のドレーンチューブ留置に対する患者の不快感，違 和感を軽減する印象を受けた。

患者の術後経過を快適なものとするための鎮痛対 策により，患者が不利益を被るようなことはあって はならない．術後鎮痛法の合併症や副作用，とくに 薬剤の副作用に関してはこれを完全に予防すること は困難であり，それらを早期に発見し，対処するこ とが大切である。

術後鎮痛法の一つとして intravenous-patient controlled analgesia (IV-PCA) があり，現在，塩酸 モルヒネを主体として施行され良好な鎮痛効果を得 ている，当院で行っているフェンタニル持続静脈内 
投与は，患者の需要にかかわらずフェンタニルが投 与され続けるため, IV-PCAに比べ安全性, 投与量 における患者の自己調節性という点で劣っている. 各患者の疼痛あるいは鎮痛薬に対する感受性などの 個人差に対応し，より安全で有効な術後鎮痛を可能に するため, PCAを導入することが今後の課題である.

\section{おわりに}

フェンタニル持続静脈内投与による術後鎮痛法 は，トレーニングを必要とすることなしに容易に施 行でき，合併症の少ない方法と思われる，今後検討 すべき点は多いものの, 適応範囲が広く, 比較的安 全な鎮痛法と考えられる。しかし，フェンタニルを 主体とした薬剤の副作用に対しては，やはり術後患
者の看視が重要であると思われる.

\section{参考文献}

1）渋谷欣一，小松徹ほか：エンドポイント指向型バラン 久麻酔，バランス麻醉：最近の進歩．克誠堂出版，東 京, 2000, $117 \sim 125$

2) Hughes MA, Glass PS, Jacobs JR : Context-sensitive half-time in multicompartment pharmacokinetics models for intravenous anesthetic drugs. Anesthesiology $76: 334 \sim 341,1992$

3）明石学, 柴田康之, 洪淳憲ほか：フェンタニル持続静 脈内投与による術後鎮痛. 日臨麻会誌 $23 ： 218 \sim 226$, 2003

4) Chien CC, Pasternak GW : Selective antagonism of opioid analgesia by a sigma system. J Pharmacol Exp Ther $271: 1583 \sim 1590,1994$ 


\title{
Intraoperative and Postoperative Intravenous Fentanyl Analgesia and Management of Postoperative Complications
}

\author{
Nobuhisa KANDATSU, Yasuyuki SHIBATA, Mitsuru HIROKAWA, \\ Kiyoshi HORIBA, Toru KOMATSU \\ Department of Anesthesiology, Aichi Medical University School of Medicine
}

Background : Postoperative analgesia may improve postoperative outcome and have appreciable effect on the surgical stress response. Operative and postoperative analgesia has become a major concern for anesthesiologists. We have reviewed the efficacy and side effects of continuous intravenous fentanyl with disposable infusion pump for postoperative pain relief. Method : Five hundred five patients received postoperative continuous intravenous fentanyl with disposable infusion pump for pain relief between January 2002 and December 2002. Four hundred fifty-seven of these patients for whom complete outcome data were available were enrolled for the study. Postoperative pain relief, the level of consciousness, respiratory and cardiovascular depression, nausea, and vomiting were evaluated retrospectively. Results : Upon arrival to the ward, 299 patients $(65.4 \%)$ had clear consciousness, $148(32.4 \%)$ somnolence, and $10(2.2 \%)$ poor recovery. Three patients $(0.7 \%)$ were delirious. Seventeen patients $(3.7 \%)$ had airway obstruction and airway opening maneuvers was needed for 5 of these patients. Two patients $(0.4 \%)$ had apnea for short period. Twenty patients $(4.4 \%)$ had $\mathrm{SpO}_{2}$ less than $90 \%$ either with or without face-mask oxygen delivery. Ten patients $(2.2 \%)$ and $43(9.4 \%)$ had a heart-rate of less than $50 \mathrm{bpm}$, and systolic blood pressure less than $90 \mathrm{mmHg}$, respectively. Seventy-seven patients $(21 \%)$ had postoperative nausea and 55 $(12 \%)$ vomiting. Pain scores were satisfactory in approximately half of the total patients without the supplement of the postoperative analgesics. Thirty-four patients $(7.2 \%)$ required a supplement of other analgesics more than 3 times during postoperative 24 hours. Conclusion : Intraoperative and postoperative continuous intravenous fentanyl analgesia is an easy and reliable option for postoperative analgesia as an alternative to the epidural analgesia.

Key Words : Fentanyl, Continuous Intravenous Administration, Postoperative Analgesia

The Journal of Japan Society for Clinical Anesthesia Vol. 24 No.10, 2004 